\title{
Author Correction: Alkaline Ethanol Oxidation Reaction on Carbon Supported Ternary PdNiBi Nanocatalyst using Modified Instant Reduction Synthesis Method
}

\author{
Bernd Cermenek $^{1}$ (D) Boštjan Genorio ${ }^{2}$ (D) $\cdot$ Thomas Winter $^{1} \cdot$ Sigrid Wolf ${ }^{1} \cdot$ Justin G. Connell ${ }^{3}$ Michaela Roschger $^{1}$. \\ Ilse Letofsky-Papst ${ }^{4} \cdot$ Norbert Kienzl $^{5} \cdot$ Brigitte Bitschnau $^{6}$ (D) Viktor Hacker $^{1}$ (i)
}

Published online: 24 November 2020

(C) The Author(s) 2020

\section{Author Correction: Electrocatalysis}

https://doi.org/10.1007/s12678-019-00577-8

The original version of this article unfortunately contained some mistakes that need to be corrected.

1. Equations on page 204 should be changed as follows:

$\mathrm{Pd}^{0}+\mathrm{OH}^{-} \leftrightarrows \mathrm{Pd}^{0}-\mathrm{OH}_{\mathrm{ads}}+\mathrm{e}^{-}$

$$
\begin{aligned}
& \mathrm{Pd}^{0}+\mathrm{CH}_{3} \mathrm{CH}_{2} \mathrm{OH} \leftrightarrows \mathrm{Pd}-\left(\mathrm{CH}_{3} \mathrm{CHOH}\right)_{\mathrm{ads}} \\
& \mathrm{Pd}-\left(\mathrm{CH}_{3} \mathrm{CHOH}\right)_{\mathrm{ads}}+3 \mathrm{OH}^{-} \leftrightarrows \mathrm{Pd}-\left(\mathrm{COCH}_{3}\right)_{\mathrm{ads}} \\
& \quad+3 \mathrm{H}_{2} \mathrm{O}+3 \mathrm{e}^{-} \\
& \mathrm{Pd}-\left(\mathrm{COCH}_{3}\right)_{\mathrm{ads}}+\mathrm{Pd}-\mathrm{OH}_{\mathrm{ads}} \leftrightarrows \mathrm{Pd}-\left(\mathrm{C}(\mathrm{OH})_{2} \mathrm{CH}_{3}\right)_{\mathrm{ads}} \\
& \quad+\mathrm{Pd}^{0} \\
& \mathrm{Pd}-\left(\mathrm{C}(\mathrm{OH})_{2} \mathrm{CH}_{3}\right)_{\mathrm{ads}}+\mathrm{OH}^{-} \leftrightarrows \mathrm{Pd}^{0}+\mathrm{CH}_{3} \mathrm{COO}^{-}+\mathrm{H}_{2} \mathrm{O}
\end{aligned}
$$

The online version of the original article can be found at https://doi.org/ 10.1007/s12678-019-00577-8

\footnotetext{
Bernd Cermenek

bernd.cermenek@gmail.com; bernd.cermenek@tugraz.at

$\triangle$ Viktor Hacker

viktor.hacker@tugraz.at
}

1 Institute of Chemical Engineering and Environmental Technology, Fuel Cell Systems Group, Graz University of Technology, NAWI Graz, Inffeldgasse 25/C, 8010 Graz, Austria

2 Faculty of Chemistry and Chemical Technology, University of Ljubljana, Večna pot 113, 1000 Ljubljana, Slovenia

3 Materials Science Division, Argonne National Laboratory, 9700 South Cass Avenue, Lemont, IL 60439, USA

4 Institute for Electron Microscopy and Nanoanalysis and Center for Electron Microscopy, Graz University of Technology, NAWI Graz, Steyrergasse 17, 8010 Graz, Austria

5 Bioenergy 2020+ GmbH, Inffeldgasse 21/B, 8010 Graz, Austria

6 Institute of Physical and Theoretical Chemistry, Graz University of Technology, Stremayrgasse 9, 8010 Graz, Austria 

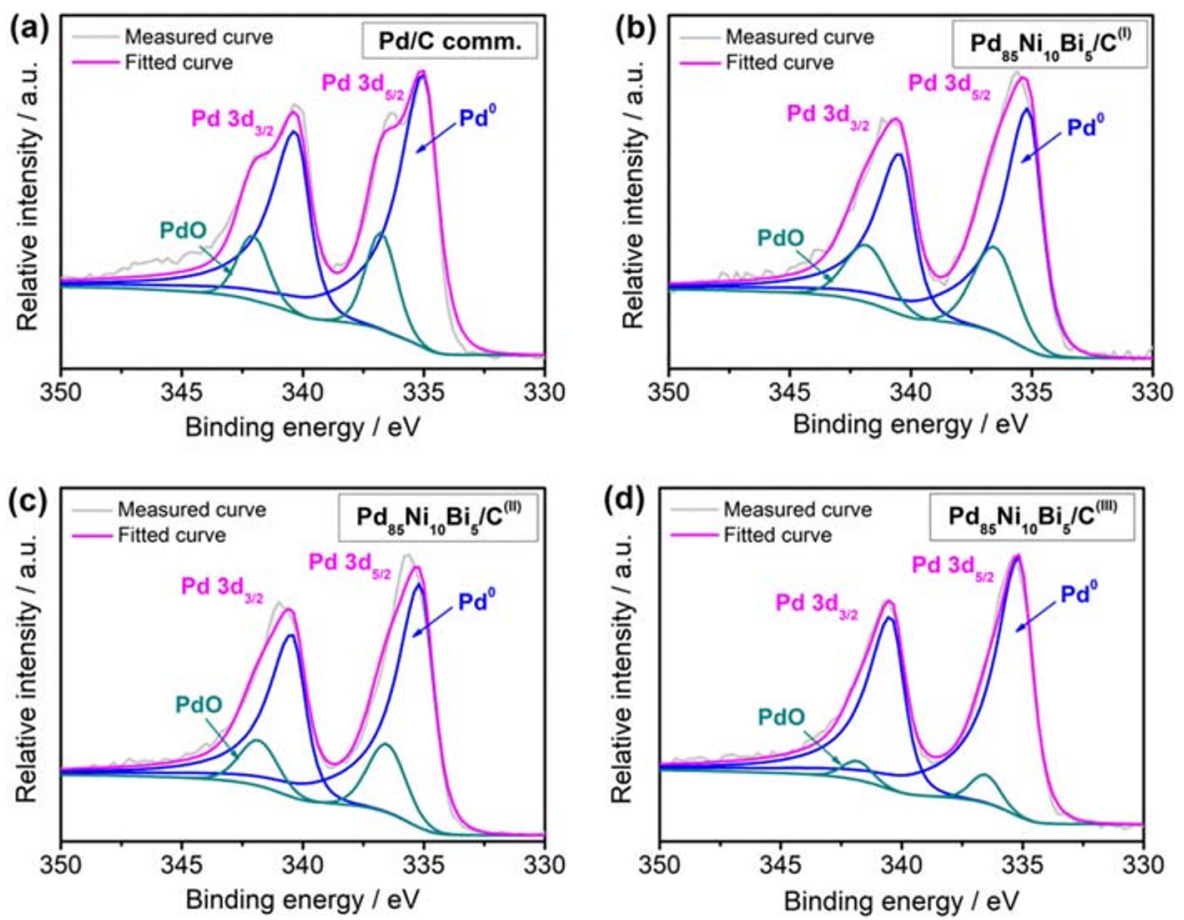

2. Figure 5: The Y unit (Relative intensity) is not (eV), but (a.u). The XPS spectra in Figure 5 should be replaced with the above:

Publisher's Note Springer Nature remains neutral with regard to jurisdictional claims in published maps and institutional affiliations. 